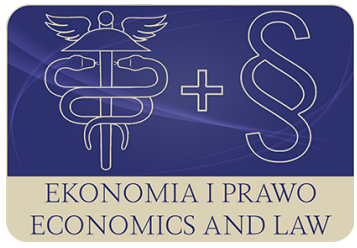

EKONOMIA I PRAWO. ECONOMICS AND LAW

Volume 15, Issue 3, September 2016

p-ISSN 1898-2255, e-ISSN 2392-1625

www.economicsandlaw.pl

ORIGINAL ARTICLE

received 06.12.2016; revised 23.01.2017; accepted 23.01.2017

Citation: Huterska, A. (2016). The rates of retirement benefits and the poverty line. Ekonomia $i$

Prawo. Ecomomics and Law, 15(3): 335-346. doi:10.12775/EiP.2016.022.

\title{
The rates of retirement benefits and the poverty line
}

\author{
AGNIESZKA HUTERSKA \\ Nicolaus Copernicus University, Faculty of Economic Sciences and Management, Department \\ of Finance, ul. Gagarina 13A, 87-100 Toruń, Poland \\ $\square$ huterska@umk.pl
}

\begin{abstract}
Aim: The aim of the article is to assess how the changes of the pension system can influence the rates of retirement benefits taking into consideration the threat of poverty for their recipients.

Motivation: The paper includes data published by the Central Statistical Office of Poland (GUS) concerning the number of retired people in Poland, the amount of received benefits, an average wage in the years 1995-2014 and the amount of the minimum subsistence and the living wage of a one-person household published by the Institute of Labour and Social Policy.

Results: It results from the considerations presented in the article that the minimum pension from the public system will not prevent poverty of elderly people.
\end{abstract}

Keywords: pension system; minimum subsistence; living wage

JEL: I32; Z130

\section{Introduction}

Demographic changes occurring in the Polish society that relate to low birth rates imply a number of changes having an impact on the economy, the pension system and the state budget. It is connected with the decreasing share of people at the productive age in the society, with longevity growth and, in consequence, with the period of retirement. The Pay As You Go (PAYGO) system, which was in operation before the reform of the pension system, undoubtedly beneficial for a future pensioner, with the decreasing number of working people for 
the number of people receiving benefits, became a system impossible to sustain due to the generated costs. The introduced changes, which aim at improving the performance of the pension system from the point of view of the relation of contributions to paid pensions and relating to it supplementary financing from the state budget, enable an improvement of the situation of the Social Security Fund (FUS), though they are negative from the point of view of a future pensioner, that is a participant of the compulsory pension system.

\section{Methods}

The aim of the article is to assess how the changes of the pension system can influence the rates of retirement benefits taking into consideration the threat of poverty for their recipients. The research method used in this study consisted of an analysis of the literature on the subject and of the data published by the Central Statistical Office of Poland concerning the number of retired people in Poland, the amount of received benefits, an average wage in the years 1995-2014 and the amount of the minimum subsistence and the living wage of a one-person household published by the Institute of Labour and Social Policy. In the empirical part, structure indicators and simple methods of analysis of phenomenon dynamics such as chain indictors of dynamics were used.

The article analyses the influence of the changes in the Polish pension system on the rates of retirement benefits. The amount of minimum benefits with the poverty lines indicated by the Institute of Labour and Social Policy the minimum subsistence and the living wage were compared.

\section{Absolute poverty lines}

Poverty and threat thereof constitute a major social issue influencing not only an individual but also the whole society and country, including its finance. It causes a social dysfunction and has a disorganising effect on the life of not only an individual but also of the society. According to a survey conducted in 2010 by the GlobeScan research institute for the BBC World Service, $71 \%$ of the respondents fear poverty the most (Kumor, 2011). It is therefore crucial not only to define it, but also to indicate the method of measurement.

The concept of the poverty limit (line) was for the first time defined by an English sociologist Benjamin Seebohm Rowentree in 1988. He did it basing on the accessible medical knowledge concerning human nutrition through specifying a basket of commodities necessary to preserve physical existence and effectiveness (Golinowska, 1995). Since then the concept of the poverty line has been used in numerous countries to specify the criteria of granting social service or initiating actions in the area of social security (Golinowska, 1995). The poverty line, based on the value of the consumer basket expressed in money, include the minimum subsistence and the living wage. These two social catego- 
ries indicate poverty limits, they mean different limits, though. The living wage is a limit 'which allows meeting basic biological needs on the lowest acceptable levels' (Dziubińska-Michalewicz, 2001), that is a level below which the possibility to secure life sustainability, preserving health and ability to work does not exist (Deniszczuk \& Sajkiewicz, 1995). The minimum subsistence is the upper limit of poverty which specifies the level of income which ensures satisfying the basic living and consumer needs on a low level (Dziubińska-Michalewicz, 2001). Those lines which specify the value of an indicated consumer basket are called absolute poverty lines. Relative poverty lines that are determined as a particular percent of median or average expenditure or income of households are also indicated (Szukiełojć-Bieńkuńska, 1995). We can also talk about subjective poverty lines, that is the level of income indicated by the public opinion on the basis of survey methodology and considered by respondents as sufficient to meet basic needs (Golinowska, 1995). This article relates to the absolute poverty lines indicated by the Institute of Labour and Social Policy in Poland calculated on the basis of the value of a consumer basket allowing meeting basic living needs. The scope and level of satisfied needs according to the model that indicates the minimum subsistence should "provide such conditions that on every stage of human development the reproduction of a human's life forces, having and upbringing children and maintaining social connections are enabled (Gimalska, 2013). It is therefore such a level of income that allows normal participation in social life (Golinowska, 1995). Lower income threatens with falling below the threshold of poverty.

The minimum subsistence, that is an indicator measuring the cost of living of households of limited means, in Poland has been estimated and published since 1981 by the Institute of Labour and Social Policy (IPiSS) under the Resolution of the Council of Ministers no. 165 of 1981. The living wage was estimated for the first time in Poland in 1995 also by the Institute of Labour and Social Policy (IPiSS).

In Poland the social security benefits on the minimum level (minimum pension and invalidity pension, welfare system benefits) are established not according to the poverty lines, but they are calculated in proportion to the average wage. Those lines show though what level of consumption the minimum pension can satisfy.

\section{Reforms of the pension system in Poland and their impact on the rates of benefits}

The number of pensioners receiving benefits from the Social Insurance Institution (ZUS) in 2014 amounted to 4,944 thousand (chart 1) and this figure remains at a stable level. Pension rates are presented in chart 2.

Growing burden on the system forced a reform of the pension system. Analysing the data it presents, it can be stated that the number of pensioners receiving lower benefits of up to PLN 1,000 is gradually decreasing, whereas 
the number of pensioners receiving higher benefits is increasing. From such a 'superficial' view of the data wrong conclusions of a decreasing poverty threat of pensioners can be drawn. It results largely from the rules on which the retirement benefits paid to the people already receiving them were calculated, as they include the people whose benefits are paid basing on the system of defined benefit, which is beneficial for a receiver, but expensive for the social insurance system. The demographic changes taking place in the society (lower fertility rate, labour migration of young people) causing the decrease in the number of working people in relation to the number of people receiving retirement benefits forced the introduction of the pension system reform. It was supposed to reduce the burden of the state budget supporting the pension system. The reform of the pension system introduced in 1999 divided the society into three groups. People born before January 1, 1949 belonged to the first group (Act of Social Insurance System, 1998). They were to receive pensions calculated with the old principles, that is according to the defined benefits system. Its amount was calculated with the formula (1) (Kołosowska, 2004).

$$
\begin{aligned}
& E=C+I, \\
& C=24 \% \cdot K b, \\
& I=[(s \cdot 1.3 \%)+(n s \cdot 0.7 \%)] \cdot P,
\end{aligned}
$$

where:

$C$ - the social part,

$I$ - the part depending on working years and wage,

$K b$ - base amount,

$S$ - contributory periods in months,

ns - non-contributory periods in months,

$P$ - basis for the determination of the retirement benefit.

The factors determining the amount of pension in the defined benefits system are as follows:

- contributory and non-contributory periods,

- the amount of income as the basis for the determination of the social security contribution,

- base amount.

It must be noticed that the amount of the social part does not depend on a person insured, but on the amount of the average wage in the year preceding retiring less the social security contributions. Also the amount of the part depending on the working years and wage is influenced by the amount of the average wage, to which individual amounts constituting the basis for contributions relate, where an insured person could choose ten consecutive years from twenty years preceding the retirement (Kołosowska, 2004). A significant part of currently paid pensions was calculated basing on the formula (1).

Another group is made up of people born between January 1, 1949 and December 31, 1968. They could choose between the old system and the new sys- 
tem (Act of Social Insurance System, 1998; Rutecka, 2012).The new system was based on three pillars, where the amount from the first pillar was calculated with the formula (2) (Kołosowska, 2004):

$$
E I=(\Sigma S+K p) / n,
$$

where:

$\Sigma S$ - the total of indexed social security contributions booked on an insured person's account, $K p$ - initial capital,

$n$ - life expectancy for people at the age equaling the age of retirement of a person insured expressed in months.

However, when the usually less beneficial new system was chosen, a paid benefit depended on the rate of collected contributions to a lesser extent than in the case of people belonging to the third group, that is those born after December 31, 1968. In the case of people from the second group, the sum of indexed contributions was increased by initial capital calculated with the formula of the defined benefit, where the social part was multiplied by a coefficient in proportion to the age of an insured person, contributory and non-contributory periods.

In the new system, a part of the contributions went to Open Pension Funds (OFE) and constituted the second capital pillar. The factors influencing the pension rate in the reformed system were (Szumlicz, 2006):

- the rate of paid retirement contributions and the period of contributions accumulation the amount of accumulated amount depended on, and also

- predicted period of receiving benefits calculated as an average life expectancy for people at the age equalling the age of an insured person.

A social element does not occur here.

Chart 3 presents the number of pensioners receiving benefits from ZUS according to the rate of benefits. It can be noticed that in this group the number of people receiving benefits from the lowest category is gradually decreasing, and the number of people receiving bigger benefits is increasing.

Let us take a closer look at the distribution of pension rates in 2014. It can be noticed that in the analysed year, 222.8 thousand people (about $4.5 \%$ of all pensioners) received pensions of up to PLN 900, where minimum pension amounted to PLN 844.45 gross. 3371.8 thousand people (68.2\%) received less than PLN 2.200, and 1.572.4 thousand people (31.8\%) received more than that, where average pension amounted to 2.117.35 (chart 3).

However, if a pension rate is related to the gross minimum wage (1.680), it emerges that $48 \%$ of pensioners receive benefits smaller than the minimum wage. Such a distribution of benefits cannot be translated directly to the rate of benefits future pensioners will receive. The group of current pensioners is dominated by those receiving benefits calculated with the rules of the defined system. Pensioners receiving benefits according to the reformed rules also be- 
long to the group with the initial capital, that is in the case of whom the social element was taken into account when the amount of benefit was calculated.

Although the rate of gross average pension and an invalidity pension have been growing (chart 4, nominal approach), the situation will change once people born after December 31, 1968 start receiving benefits.

\section{The distribution of the amount of the retirement benefits}

Presenting the development of the rate of an average monthly salary and pension (chart 4), a growing disproportion between them, resulting also from a decreasing replacement rate, can be seen.

The ratio of an average pension to an average salary (chart 5), that is the replacement rate measured as a ratio of an average gross monthly pension to an average gross salary in the Polish economy in 2014, which was considerably reduced when compared with the year 1994, is going to be reduced even more.

Chart 5. Ratio of an average pension to an average salary (the replacement rate measured as a ratio of an average gross monthly pension to an average gross salary in the Polish economy in the years 1994-2014).

Taking into account the fact that the wage distribution with the use of righthanded asymmetry distribution (according to the data of the Central Statistical Office of Poland, in 2014 the wage distribution was as follows: the mode of PLN 2,469.47, the median of PLN 3,291.56, the average wage of PLN 4,107.72) in the case of pensions calculated with the new rules, whose rate depends on the amount of the contributions, thus also on earnings, most Polish people can count on at most minimum pensions in the future.

The phenomenon is confirmed by the presented in chart 6 comparison of the number of pensioners receiving benefits from ZUS according to the rate of those benefits compared with the rate of minimum pension of PLN 844.45 and an average pension from ZUS of PLN 2,117.35 from 2014.

\section{Comparison of minimum retirement benefits with the poverty lines}

Chart 7 compares the development of the minimum pension rate, survivor's pension and annuities for a person incapable of work and the minimum subsistence and the living wage.

Although the ratio of minimum pension to the living wage amounts to 1.6, the ratio of the minimum pension to the minimum subsistence has reached the level of 0.8 (chart 8 ). The presented rates of the lowest benefit are not gross rates, and thus the relations must get even lower. 


\section{Conclusion}

It results from the considerations presented in the article that the minimum pension from the public system will not prevent poverty of elderly people. Taking into account the risk of longevity and the lack of the possibility to have extra work added to the benefits from the compulsory system and in the situation when aged people do not have any savings at their disposal, the future may see a problem resulting from the burdening of the public finance system with benefits of the social assistance. The next problem is a low inclination of working people to save money voluntarily in order to ensure additional funds after the termination of professional activities. Also young people entering the labour market often do not consider saving money in case they terminate their professional activities putting consumption before pension savings. Another issue that is worth considering is the equivalence of benefits paid in the future and the contributions. It is particularly important in the case of people with low wages, whose amount has a limiting impact on the possibility to accumulate money individually in order to support income after the termination of paid employment.

\section{References}

Deniszczuk, L. \& Sajkiewicz, B. (1995). Minimum egzystencji. Polityka Spoteczna, 8(260).

Dziubińska-Michalewicz, M. (2001). Minimum egzystencji a minimum socjalne. Retrieved 10.09.2016 from http://biurose.sejm.gov.pl.

Gimalska, E. (Ed.). (2013). Minimum socjalne i minimum egzystencji. Retrieved 10.09.2016 from https://www.ipiss.com.pl.

Golinowska, S. (1995). Linie ubóstwa w praktyce społecznej krajów transformacji. Polityka Spoteczna, 8(260).

GUS. (1995-2014). The Statistical Yearbook of the Republic of Poland for the years 1995-2014. Retrieved 10.09.2016 from http://stat.gov.pl.

Infor.pl. (2016). Retrieved 10.09.2016 from http://www.infor.pl.

IPiSS. (2016). Retrieved 10.09.2016 from https://www.ipiss.com.pl.

Kołosowska, B. (2004). Skutki finansowe reformy systemu emerytalnego w Polsce. Torun: Wydawnictwo UMK.

Kumor, I. (2011). Ubóstwo - ujęcie teoretyczne. Edukacja Humanistyczna, $1(24)$.

Rutecka, J. (2012). Zakres redystrybucji dochodowej w ubezpieczeniowym systemie emerytalnym. Warszawa: Oficyna Wydawnicza SGH.

Szukiełojć-Bieńkuńska, A. (1995). Relatywna linia ubóstwa i wyniki jej zastosowania w badaniach budżetów rodzinnych w 1993 i 1994 r. Polityka Spoteczna, $8(260)$.

Szumlicz, T. (2006). Ubezpieczenie spoteczne, teoria dla praktyki. BydgoszczWarszawa: Oficyna Wydawnicza Branta. 
Ustawa z dnia 13 października 1998 r. o systemie ubezpieczeń społecznych [Act of Social Insurance System of October 13, 1998] (Dz.U. 1998 nr 137 poz 887) (Poland).

\section{Acknowledgements}

Author contributions: author have given approval to the final version of the article.

Note: the results of this study were presented in another form, such as a presentation at a conference. 


\section{Appendix}

Chart 1.

The number of pensioners from ZUS altogether (in thousands of people)

6000

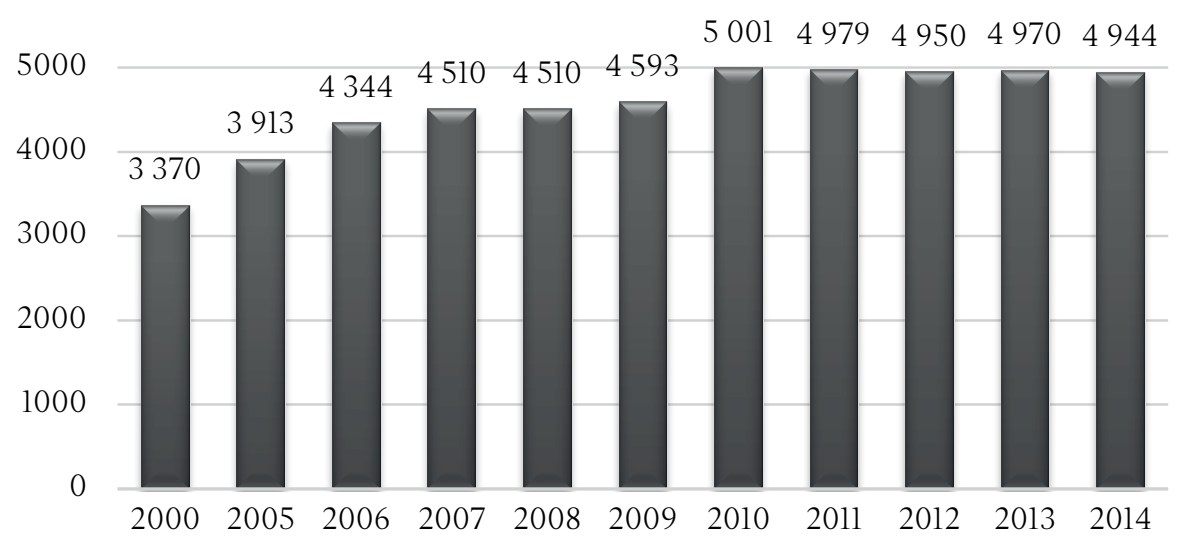

Source: own calculations based on GUS (2000-2014).

Chart 2.

The number of pensioners from ZUS according to the rate of benefits (in thousands of people)

1500

1000

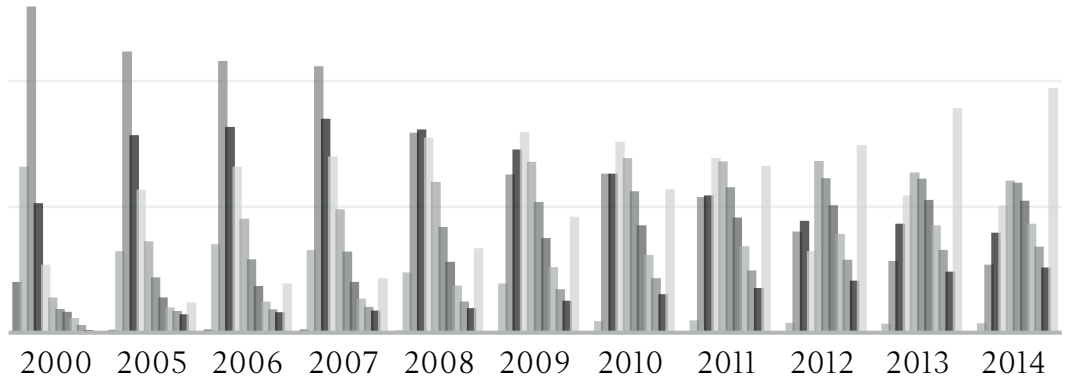

$\begin{array}{llll}\square \text { up to } 500.00 & 500.01-700.00 & \square 00.01-1000 & \square 1000.01-1200 \\ 1200.01-1400 & \square 1400.01-1600 & \square 1600.01-1800 & 1800.01-2000 \\ 2000.01-2200 & 2200.01-2400 & \square 2400.01-2600 & 2600.01 \text { and above }\end{array}$

Source: own calculations based on GUS (2000-2014). 
Chart 3.

The amount of a pension from ZUS according to benefit rates (in \%)

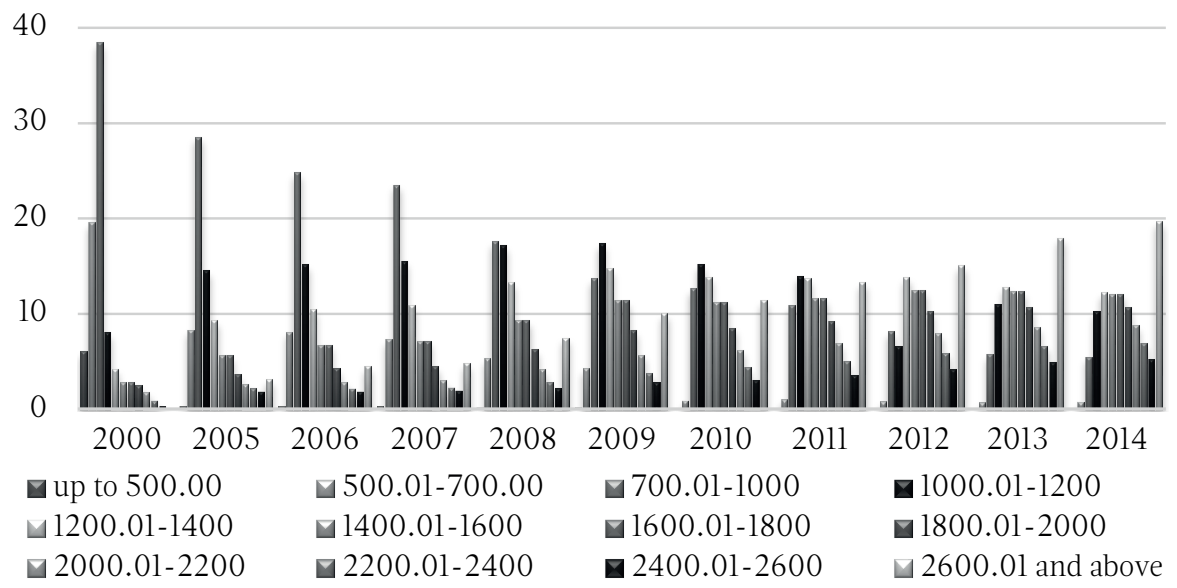

Source: own calculations based on GUS (2000-2014).

\section{Chart 4.}

An average monthly salary and pension (in PLN)

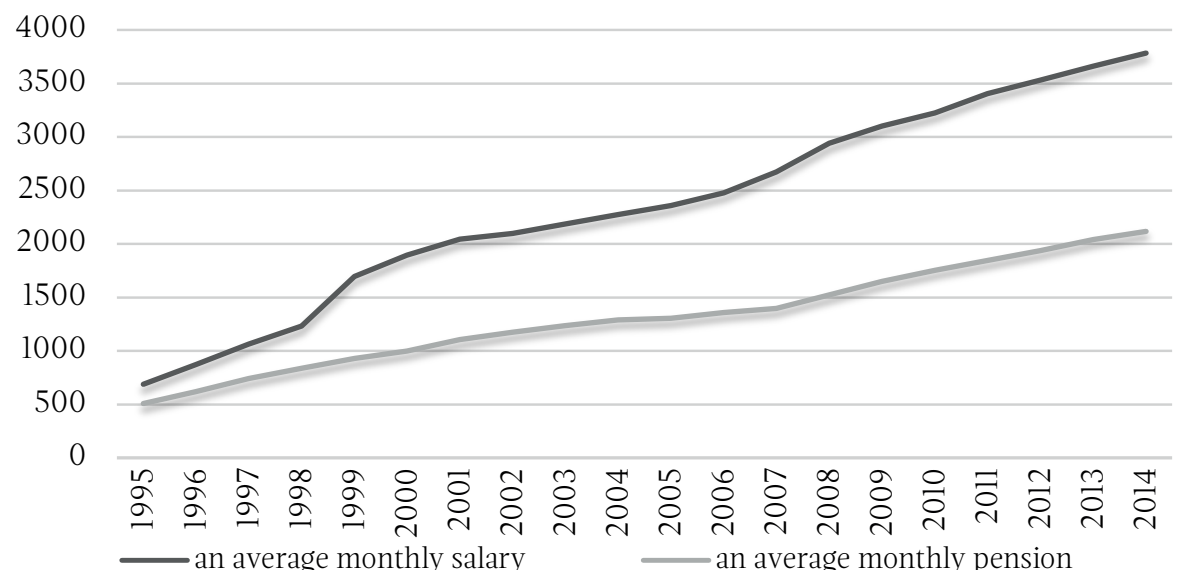

Source: own calculations based on GUS (1995-2014). 


\section{Chart 5.}

Ratio of an average pension to an average salary in the years 1994-2014) (in \%)

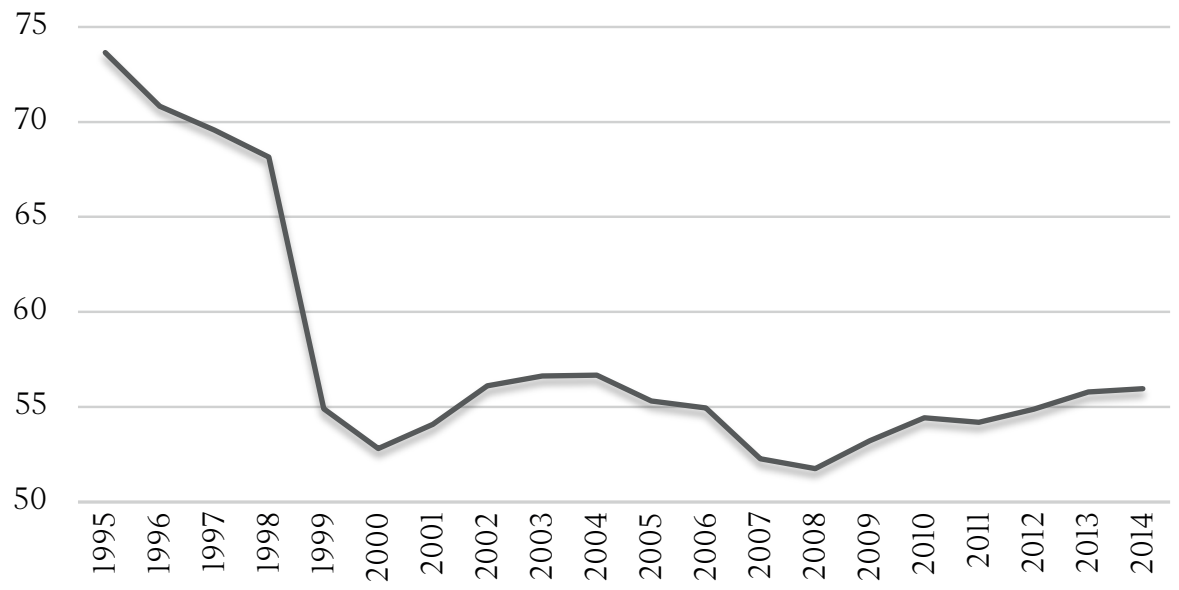

The replacement rate measured as a ratio of an average gross monthly pension to an average gross salary in the Polish economy.

Source: own calculations based on GUS (1995-2014).

\section{Chart 6.}

The number of pensioners from ZUS according to the rate of benefits in thousands of people in 2014 (in PLN)

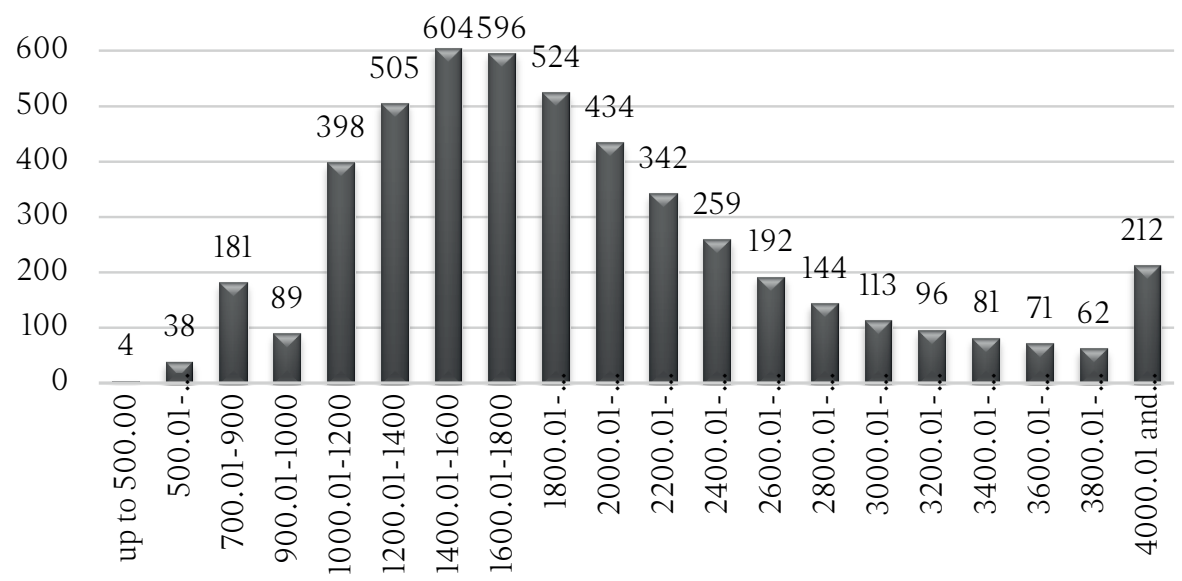

Source: own calculations based on GUS (2014). 


\section{Chart 7.}

The lowest pension, survivor's pension and annuities for a person incapable of work and the minimum subsistence and the living wage (in PLN)

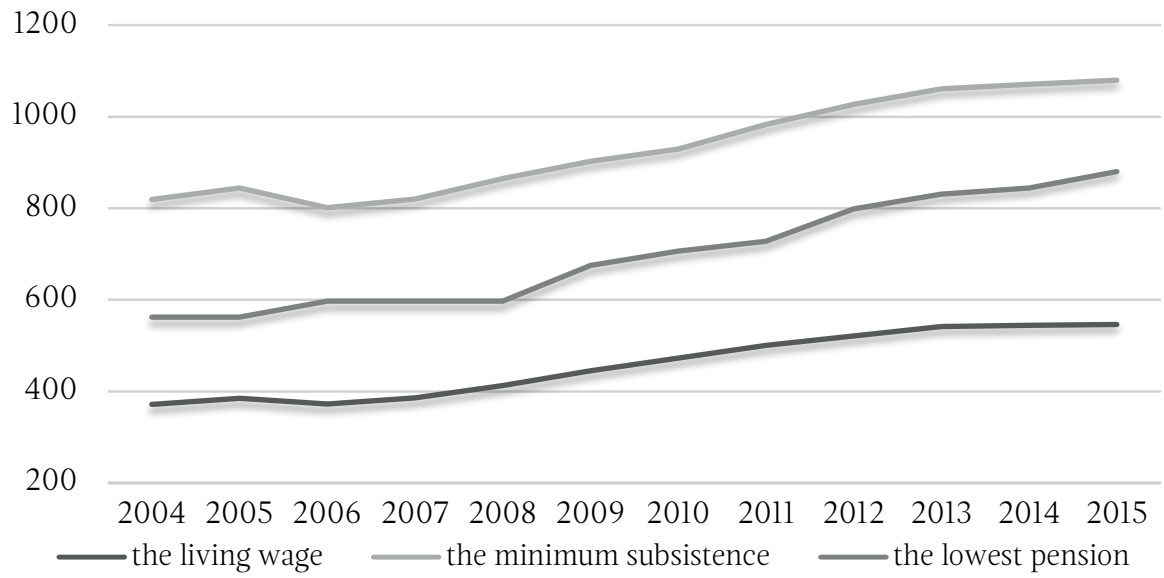

Source: own calculations based on the data from Infor.pl (2016) and IPiSS (2016).

\section{Chart 8.}

The ratio of lowest pension, survivor's pension and annuities for a person incapable of work to the minimum subsistence and the living wage

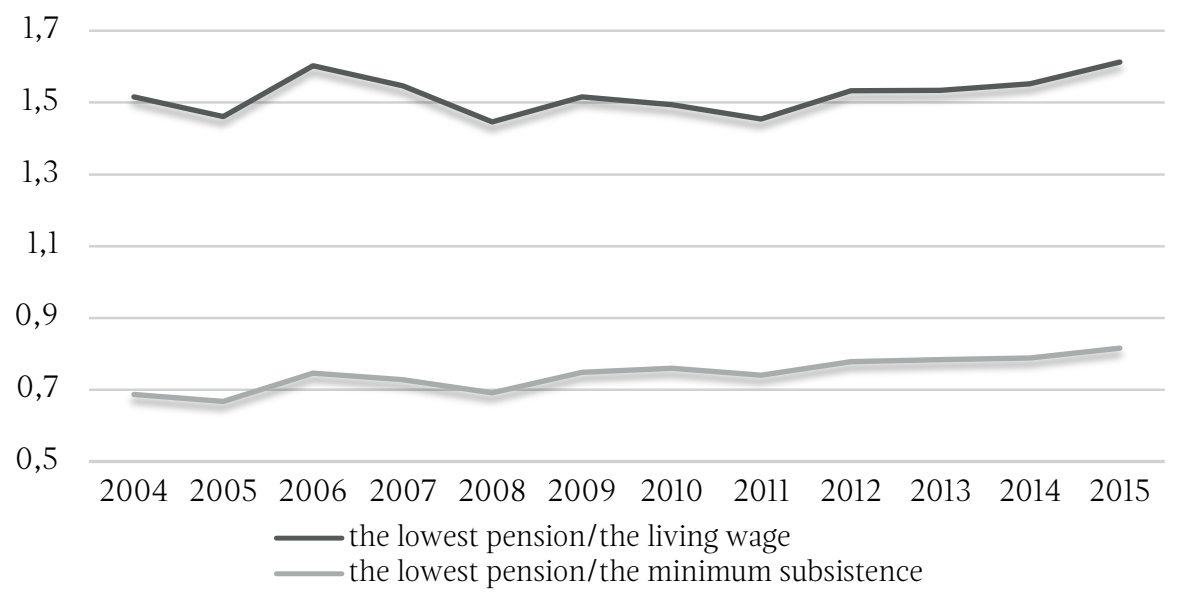

Source: own calculations based on the data from Infor.pl (2016) and IPiSS (2016). 